Curr Genet (1988) 13:49-56

\title{
Mitochondrial DNAs of Suillus: three fold size change in molecules that share a common gene order
}

\author{
Thomas D. Bruns ${ }^{1, *}$, Jeffrey D. Palmer ${ }^{1}$, Deborah S. Shumard ${ }^{2}$, Lawrence I. Grossman ${ }^{3}$, and Michael E. S. Hudspeth ${ }^{2}$ \\ 1 Department of Biology, University of Michigan, Ann Arbor, MI 48109-1048, USA \\ 2 Department of Biological Sciences, Northern Illinois University, Dekalb, IL 60115-2861, USA \\ 3 Department of Molecular Biology and Genetics, Wayne State Univeristy, School of Medicine, 540 E. Canfield, Detroit, MI 48201, USA
}

Summary. We constructed restriction-site and gene maps for mitochondrial DNAs from seven isolates of five species of Suillus (Boletaceae, Basidiomycotina). Each mitochondrial genome exists as a single circular chromosome, ranging in size from 36 to $121 \mathrm{~kb}$. Comparisons within species and between two closely related species revealed that insertions and deletions are the major form of genome change, whereas most restriction sites are conserved. Among more distantly related species, size and restriction-site differences were too great to allow precise alignments of maps, but small clusters of putatively homologous restriction sites were found. Two mitochondrial gene orders exist in the five species. These orders differ only by the relative positions of the genes for ATPase subunit 9 and the small ribosomal RNA and are interconvertible by a single transposition. One of the two gene arrangements is shared by four species whose mitochondrial DNAs span the entire size range of 36 to $121 \mathrm{~kb}$. The conservation of gene order in molecules that vary over three-fold in size and share few restriction sites demonstrates a low frequency of rearrangements relative to insertions, deletions, and base substitutions.

Key words: Basidiomycotina - Molecular evolution Transposition - Length mutations - Gene order

\footnotetext{
* Present address: Department of Botany, University of California, Berkeley, CA 94720 , USA

Offprint requests to: $\mathrm{T}$. D. Bruns

Abbreviations: Cytochrome oxidase subunits I, II, and III $\mathrm{COI}$, COII, COIII; apocytochrome b, COB; ATP synthase subunits 6, 9 - APT6, ATP9; large and small ribosomal RNA gene LrRNA, SrRNA; mitochondrial DNA - mtDNA
}

\section{Introduction}

Our present knowledge of the structure and function of fungal mitochondrial DNA (mtDNA) has been accumulated primarily through extensive study of a few fungi, including Saccharomyces cerevisiae, Aspergillus nidulans, Neurospora crassa, Schizosaccharomyces pombe, and Torulopsis glabrata (Clark-Walker and Sriprakash 1983; Lang et al. 1983; Brown et al. 1985; Clark-Walker 1985; de Zamaroczy and Bernardi 1985; Grossman and Hudspeth 1985; Nelson and Macino 1985; Tzagoloff and Myer 1986). These fungi offer such advantages as rapid growth in culture, easily manipulated life cycles, and well characterized genetic systems. However, their value in illuminating patterns of fungal mtDNA evolution is limited by their rather distant relationships to one another. Studies of intraspecific variation have been conducted in several of these species and provide the basis for our current understanding of frequent molecular evolutionary events (Sanders et al. 1977; Collins and Lambowitz 1983; Taylor et al. 1986). Thus, comparisons of mtDNAs between and within these fungal species allow one to assess the extremes of divergence within the molecule.

Intermediate levels of fungal $m t D N A$ divergence have been largely neglected. Studies by Jacquier and Dujon (1983), and Hoeben and Clark-Walker (1986) are significant exceptions. Both examined mtDNAs among related species and genera of yeasts. The former study focused on one region of the molecule by surveying the distribution of the omega intron of the large ribosomal RNA gene (LrRNA). The latter involved gene mapping of the entire molecule in seven species and documented identical gene orders among the mtDNAs of three species. The gene orders of four additional species could all be interrelated by two single-step rearrangements, but multiple rearrangements separated these orders from 
that found in the first three species. The current taxonomy of these yeasts conflicts with the groupings suggested by their mitochondrial gene orders (Hoeben and ClarkWalker 1986) and their mtDNA restriction-fragment patterns (McArthur and Clark-Walker 1983). However, the significance of this conflict is difficult to interpret because the taxonomy of these yeasts is based primarily on their physiological properties; few morphological clues are available to provide an independent assessment of their phylogenetic relationships.

We have compared mtDNAs within and between five species of Suillus sensu lato. Like other members of the Boletaceae, species of Suillus produce large, relatively complex basidiocarps. Morphological and anatomical features of these structures provide the basis for current systematic treatments of the genus. Prior taxonomic studies produced some differences in the classification of the genus, primarily with regard to the validity of two segregate genera, Boletinus and Fuscoboletinus (Pomerleau and Smith 1962; Smith and Thiers 1964, 1971 ; Singer 1975,1981$)$. However, with a single exception (Pegler and Young 1981), all previous researchers have thought that Suillus in the broad sense is monophyletic.

Sufficient taxonomic agreement existed to allow us to select five species expected to span a range of evolutionary relationships. Two species, Suillus viscidus (also called $S$. aeruginascens), and $S$. grisellus are considered to be closely related. They are either placed together in the subsection Megasporini of Suillus (Singer 1975, 1981) or in section Griselli of Fuscoboletinus (Smith and Thiers 1971). Two other species, S. luteus and $S$. cavipes, are thought to be more distantly related. They are separated from each other and from the former two species at either the sectional or generic levels. Less agreement exists with regard to the relationship of $S$. tridentinus, which is either placed in subsection Megasporini with $S$. viscidus and S. grisellus (Singer 1975, 1981), or segregated from these two at the generic level (cf. Smith and Thiers, 1971). In the latter classification it is considered congeneric with $S$. cavipes and $S$. luteus. In any case, several levels of phylogenetic relationships were expected to be included in our sample. In addition, to sample intraspecific variation, two isolates were examined from two of the species, S. luteus and $S$. viscidus.

We show that intraspecific variation in mtDNAs of Suillus is similar in nature to that previously described in Ascomycotina: insertions and deletions account for most of the differences found. MtDNAs of the five species vary extensively in size, ranging from 36 to $121 \mathrm{~kb}$. This variation results from numerous insertions and deletions that exist throughout the genome. These size changes have occurred without major rearrangements. Four species share a common gene order, one that is potentially related to that of the fifth species by a single transposition.

\section{Methods}

Axenic cultures of $S$. visicidus TDB-561, TDB-576, S. grisellus TDB-574, $S$. luteus TDB-571, and $S$. cavipes TDB-646 were isolated from tissue excised from basidiocarps collected in southeastern Michigan. Voucher collections of the basidiocarps are deposited at the University of Michigan Herbarium (MICH). $S$. tridentinus HB-347 and S. luteus HB-348 were kindly provided by Helmut Besl, University of Regensburg, Federal Republic of Germany. Cultures were maintained on medium M-40 (Stevens 1984), stored at $5^{\circ} \mathrm{C}$, and transferred every 3-5 months. Batch cultures were grown at $22^{\circ}$ in 16 -liter carboys in aerated liquid culture of the same medium. Total nucleic acids were isolated and mtDNA was purified from Suillus as described for Achlya (Hudspeth et al. 1983, with modifications noted in Shumard et al. 1986). Petite mtDNAs from Saccharomyces cerevisiae were isolated as previously described (Hudspeth et al. 1980).

$\mathrm{MtDNA}$ restriction endonuclease fragments were separated via gel electrophoresis $(0.7-0.8 \%$ agarose and $3.5-4 \%$ acrylamide), and sizes were estimated by comparison to known size standards (lambda phage DNA: HindIII, EcoRI, Smal, SalI fragments; Phi-X 174 phage DNA: HaeIII, RsaI fragments). Selected agarose gels were blotted onto nitrocellulose by standard techniques (Southern 1975), or onto Zetabind nylon filters by the alkaline blot method (Reed and Mann 1985). Filter blots were hybridized with ${ }^{32} \mathrm{P}$-labeled gel-isolated mitochondrial gene sequences derived from petite mutants of Saccharomyces cerevisiae. These yeast probes have been described elsewhere (Shumard et al. 1986) with the following exceptions: The $3^{\prime}$ and $5^{\prime}$ probes from the $15 \mathrm{~S}$ ribosomal RNA gene (SrRNA) are the internal 682 bp Hhal-BamHI fragment and the $756 \mathrm{bp}$ BamHIHpHI fragment (see Sor and Fukuhara 1980, and Li et al. 1982). The cytochrome oxidase subunit II (COII) probe is a $273 \mathrm{bp}$ PvuII fragment from the central portion of the gene (see Coruzzi and Tazgoloff 1979). Fragments were nick-translated by standard procedures (Maniatis et al. 1982). The small fragments for ATP synthase subunit 9 (ATP9) and COII were ligated for $1 \mathrm{~h}$ at room temperature after nick-translation and prior to denaturation (Maniatis et al. 1982). Filters were prehybridized overnight and then hybridized for $20-36 \mathrm{~h}$ at $50^{\circ} \mathrm{C}$ in $6 \times \mathrm{SSC}, 2 \times$ Denhardt's solution, $100 \mu \mathrm{g} / \mathrm{ml}$ sheared salmon sperm DNA. After hybridization the filters were washed three times at $50^{\circ} \mathrm{C}$ in $3 \times$ SSC, $0.1 \%$ SDS. Autoradiograms were exposed for 1-6 days at $-80^{\circ}$ with or without intensifying screens. Bound probes were stripped from the filters with boiling $0.1 \times \mathrm{SSC}$ prior to rehybridization.

Restriction site maps were constructed by comparisons of single, double and triple enzyme digests and by utilizing gene hybridization data.

\section{Results}

\section{Differences between closely related isolates and species}

Insertions and deletions were found to be the major source of intraspecific variation in Suillus mtDNA. Three length mutations must be postulated to account for the 


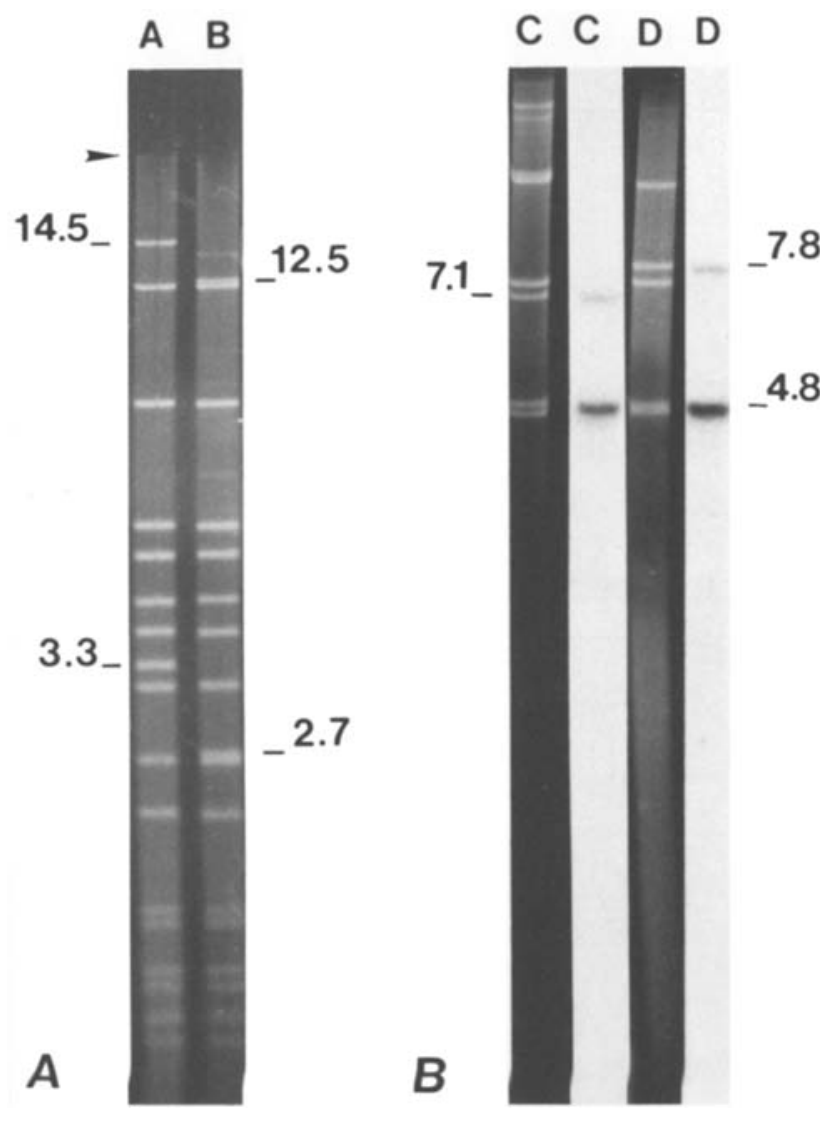

Fig. 1A, B. Length mutations in Suillus mtDNA. A AvalI digests of mtDNAs from two isolates of $S$. luteus, $571(A)$ and $348(B)$. The two size differences present correspond to the 1.9 and $0.59 \mathrm{~kb}$ length mutations mapped in Fig. 2A. The third and largest size difference between the two isolates exists in the large degraded fragment marked near the top of the gel (arrow). B Hybridization of sequences from the LrRNA gene of Saccharomyces cerevisiae to filter-bound BstEII digests of two isolates of $S$. viscidus. A $4.8 \mathrm{~kb}$ fragment that contains a portion of the LrRNA gene is conserved in both isolates. The adjacent fragment differs by approximately $0.7 \mathrm{~kb}$ as the result of length mutation. Only one BstEII site difference exists between the two isolates (Fig. 2B). Lanes $C$ and $D$ correspond to isolates 561 and 576, respectively

observed differences between two isolates of $S$. luteus, while nine separate the two strains of $S$. viscidus. These size changes range from $50 \mathrm{bp}$ to $3.9 \mathrm{~kb}$ and are scattered throughout the mitochondrial genome (Figs. 1 and 2A, B). The smallest detected difference occurs in the region near COI of Suillus viscidus. Two of the three length mutations found in $S$. luteus also map to this same general region. In $S$. luteus, however, these size changes are located on the opposite side of a pair of restriction sites (CfoI and SstII) from the $50 \mathrm{bp}$ difference found in $S$. viscidus. This pair of sites exists in two additional species and appears to be homologous (see below). Thus, three length mutations have occurred in different locations within a relatively small region.
Most of the restriction-site differences between strains are located near size-variable regions. Those that are not are confined to a single region in each species pair. The three site changes that are not associated with mapped size differences in $S$. luteus are clustered between the COII and SrRNA genes, while the two such sites in $S$. viscidus are clustered between COIII and COI (Fig. $2 \mathrm{~A}, \mathrm{~B})$. Many of the site differences that occur within or near size-variable areas probably result from insertions and deletions rather than base substitutions. In the $S$. viscidus isolates, six out of seven such site changes are in the same direction as the size change, i.e., site losses correlate with deletions and site gains with insertions (Fig. 2B). In S. luteus, three of the five site differences associated with length mutations occur in the corresponding direction. In both species, site changes that occur in the opposite direction are associated with large size changes. These large length mutations may result from several smaller insertions and deletions whose overall size difference is mapped as a single change. In this case, sites could be inserted or deleted directly by small unresolved length mutations that occur in the direction opposite to the regional net size change. An alternative explanation for the clustering of site changes in size-variable regions is that these areas are more prone to both insertions/deletions and base substitutions. However, no obvious mechanism is available to add credence to this interpreatation.

Comparisons between $S$. viscidus and a closely related species, $S$. grisellus, yield results similar to those of the two intraspecific comparisons (Fig. 2C). The primary differences are quantitative: more restriction-site changes are observed and the length mutations are on average much larger. Although there are only seven mapped size differences in this interspecific comparison compared to nine between strains of $S$. viscidus, the absolute value of these changes is much greater: $30.7 \mathrm{~kb}$ versus $11.5 \mathrm{~kb}$. The actual number of length mutations is probably underestimated because the most variable regions are characterized by a paucity of restriction sites. This fact limits our ability to resolve multiple, clustered length mutations. These regions with large length differences may differ from other portions of the molecule in base composition. With the exception of ClaI, the recognition sequences of the restriction enzymes mapped have a G-C bias. The low density of restriction sites in these regions therefore suggests that they are more A-T rich than other portions of the molecule.

Eighteen restriction-site differences occur between $S$. viscidus and S. grisellus (Fig. 2A). Eight of these occur in size-variable regions, but ten are scattered throughout size-conserved regions. This result suggests an increase in base substitutions at the interspecific level. The low density of aligned restriction sites in the regions where most of these site changes occur makes the detection 

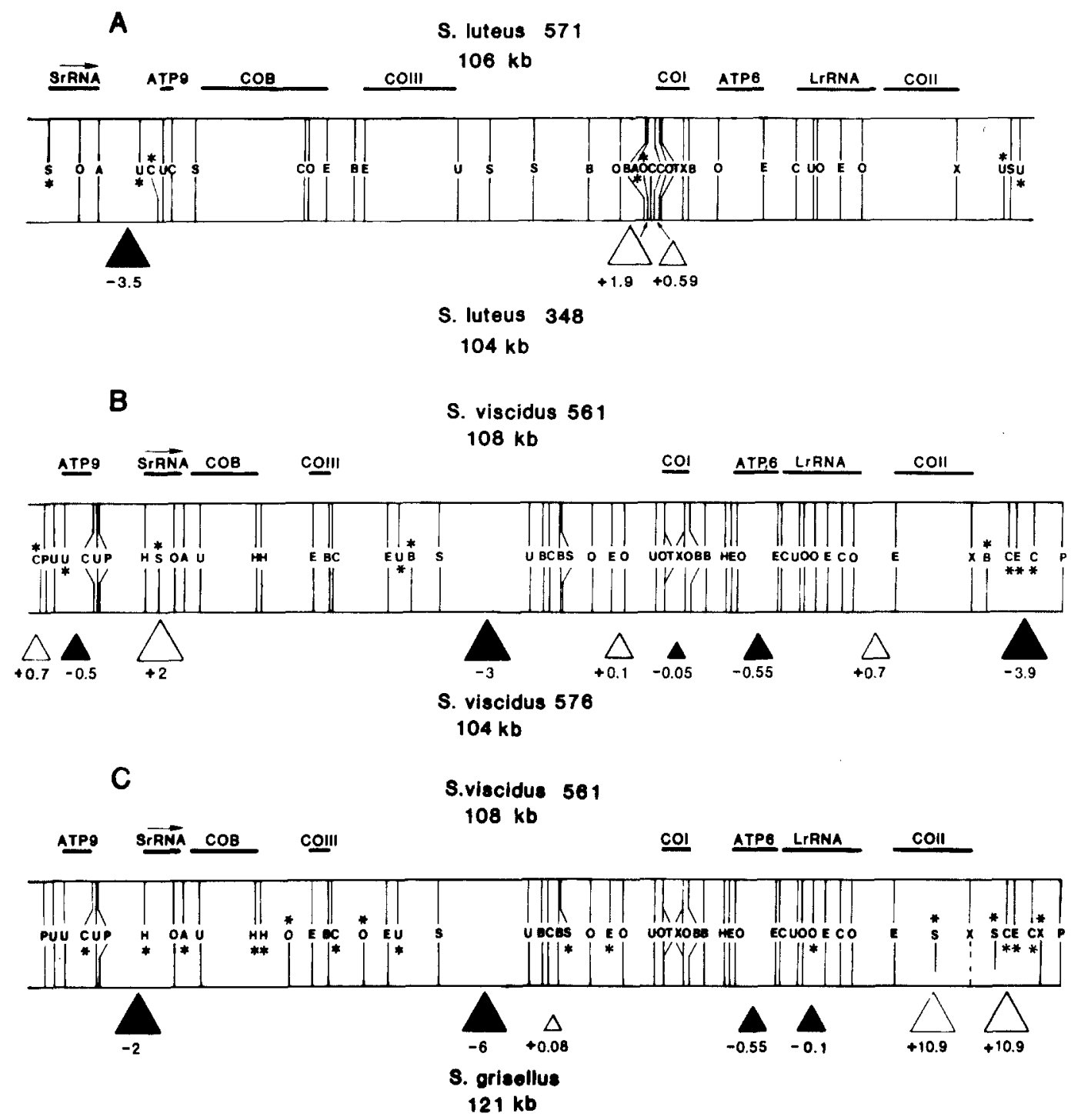

Fig. 2A-C. Variation of mitochondrial genomes within species and between two closely related species of Suillus. Linearized restriction-site maps of circular mtDNAs are illustrated in three pair-wise comparisons. The top map in each pair is drawn to scale and aligned with the bottom map by conserved restriction sites. Sites that occur in the same region of the molecules and that are equidistant from at least one other site are assumed to be homologous and are indicated by solid lines connecting site abbreviations. Unattached and broken lines indicate novel sites and putatively homologous sites within insertion/deletion regions. Asterisks indicate site differences. Deletions (solid triangles) and insertions (open triangles) in the bottom map relative to the top one are shown below each pair of maps. The magnitude of the size differences is indicated roughly by the size of the triangles and is estimated below in kilobase pairs. The regions to which eight heterologous gene probes hybridize are shown above each pair of maps. The limits of these regions are defined by the restriction sites illustrated, with the following exceptions: Weak hybridization of the LrRNA probe to the fragment left of the Cfol site is indicated by a short extension of the hybridization region beyond this site. In $S$. luteus the adjacent hybridization limit of the COII probe is arbitrarily depicted near the border of the LrRNA region. Restriction site abbreviations are as follows: (A) AvaI; (B) BamHI; (C) ClaI; (E) BstEII; (H) HaeII; (O) CfoI; (P) PstI; (S) SstI; (T) SstII; (U) PvuII; (X) XhoI

Fig. 4. Mitochondrial DNA variation among five species of Suillus. Restriction-site maps of circular mtDNAs are shown linearized in approximate alignment. Many of the restriction sites of $S$. viscidus and $S$. grisellus can be unambiguously aligned (Fig. 2). Similar alignment of sites from $S$. cavipes, $S$. tridentinus, and $S$. luteus is not possible, but clusters of similar sites can be recognized among all five species. Those clusters shared by three or more species are indicated by asterisks and are discussed in the text. The isolates of $S$. luteus and $S$. viscidus illustrated here are 571 and 561, respectively. An EcoRI site (R) that delimits the hybridization limit of the $5^{\prime}$ SrRNA probe is mapped in $S$. cavipes. Other EcoRI sites are not shown. All sites of other enzymes are indicated. Restriction sites abbreviations are as follows: (A) Aval; (B) BamHI; (C) ClaI; (E) BstII; (H) HaeII; (O) CfoI; (P) PstI; (S) SstI; (T) SstII; (U) Pvu II; (X) Xhol 


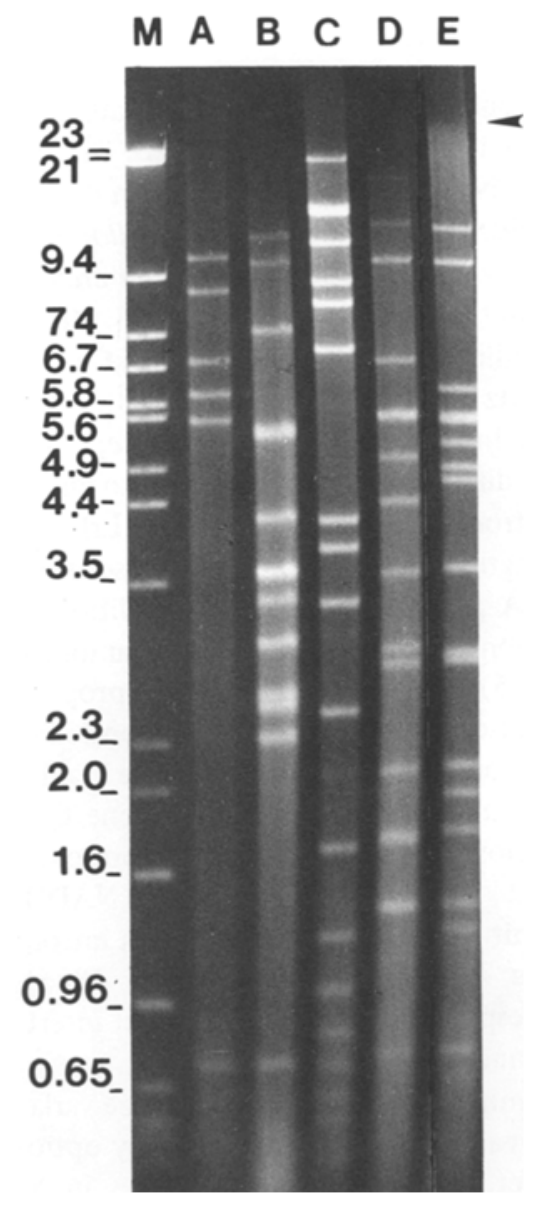

of small size changes difficult. Therefore, some of these site differences could still be the result of length mutations rather than base-substitutions.

\section{Differences among distantly related species}

The mtDNAs studied here vary over three fold in size $(36-121 \mathrm{~kb}$; Figs. 3 and 4). This size variation, together with a correspondingly greater amount of restrictionsite divergence, prevents the precise alignment of maps that was possible at lower taxonomic levels. Clusters of putatively homologous sites can, however, be recognized in all of the species (Fig. 4), although the size variation makes even these alignments tentative. These clusters are all located in or near regions to which the heterologous gene probes map.

A set of three sites, ClaI-PvuII-CfoI, occurs in all five species in the region of the LrRNA gene, and a pair of sites, Cfol-Aval, occurs near the SrRNA gene in four species. The latter CfoI site is also shared by the fifth species, $S$. grisellus, but the Aval site is absent (see Fig.

Fig. 3. Size difference among Suillus mtDNAs. HaeIII digests of the mtDNAs of $S$. cavipes $(A), S$. tridentinus $(B), S$. luteus $(C)$, $S$. viscidus $(D)$, and $S$. grisellus $(E)$ are shown in comparison to fragments of known sizes (lane $M$, lambda and phi $\mathrm{X}$ phage DNAs). Sizes of these fungal mtDNAs vary from 36 to $121 \mathrm{~kb}$ based on the mapping data from 11 enzymes (Fig. 4). Note the large degraded fragment in lane $D$ (arrow)

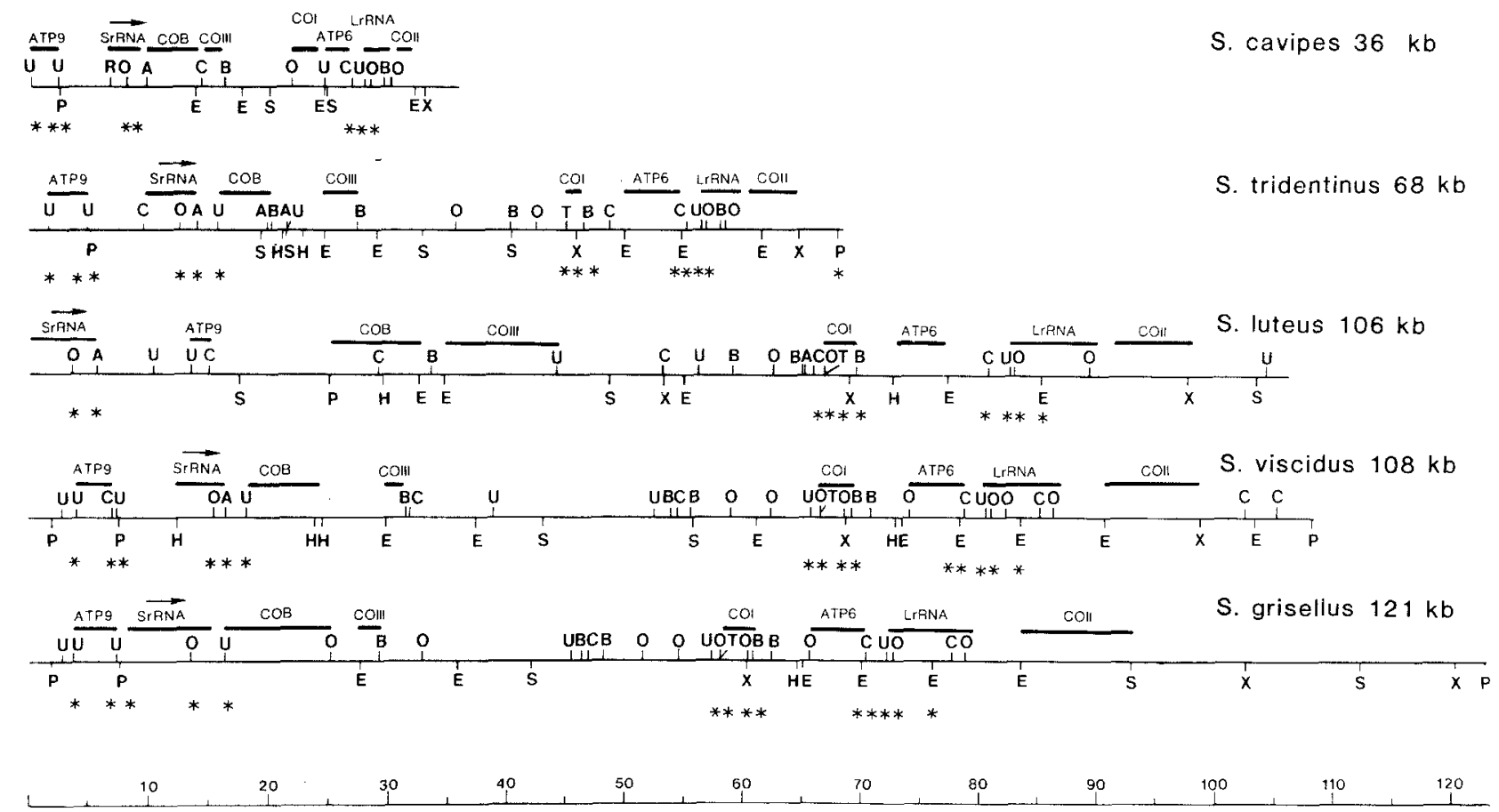


2C). Distances between the CfoI-AvaI and PvulI-CfoI pairs appear to be the same in all species. The ClaIPvull distance differs among the five species. It is 1.3 $\mathrm{kb}$ in $S$. cavipes and $S$. tridentinus and $1.8 \mathrm{~kb}$ in the other three. Evidence that this difference is caused by a length mutation rather than by the gain and loss of two different $\mathrm{ClaI}$ sites comes from the observation that a BstEII site is $0.4 \mathrm{~kb}$ from the ClaI site in $S$. tridentinus, $S$. viscidus, and S. grisellus (Fig. 4). At the other end of the. LrRNA gene an additional BamHI site and a Cfol site are shared by $S$. tridentinus and $S$. cavipes, and a BstEII site is shared by the other three species.

Three additional regions contain clusters of similar sites in some species. The COI region in all species except $S$. cavipes contains a set of three sites, SstII-XhoIBamHI. The distances between these sites are identical in $S$. viscidus and $S$. grisellus, but differ slightly in the other two species. These differences could indicate that the similarity of sites is coincidental and not due to homology. On the other hand, these three enzymes cut extremely infrequently in these molecules and, in fact, only one SstII site exists in each of the four species. Furthermore, an additional CfoI site occurs adjacent to the SstII site in $S$. luteus, $S$. viscidus and $S$. grisellus. We believe it unlikely that these sites occur by coincidence in the same order and within $2 \mathrm{~kb}$ of each other. A set of 3 sites, PvuII-PvuII-PstI, is found in the ATP9 region of four species. The PvulI-Pvull distance varies between species and also between the two isolates of $S$. viscidus (Fig. 2B), so it is not possible to be certain of the homology of both sites. One of the two sites, however, is within $0.2 \mathrm{~kb}$ of a PstI site in all four species, suggesting that both of these sites are homologous.

Many other site similarities are present throughout the mtDNAs of the five species, but length differences preclude confident recognition of homology. Maps based upon more hybridization data and with greater site densities could help to resolve this problem.

Gene order was found to be the most conservative feature of these molecules. A common gene order is shared by four of the species, whose mtDNAs vary in size from 36 to $121 \mathrm{~kb}$. The gene arrangement of $S$. luteus mtDNA differs only by the relative positions of the ATP9 and SrRNA genes. The orientation of the latter gene is identical in all five species (Fig. 4). The only single-step pathway to interconnect these two gene arrangements involves transposition of either gene. Two inversions could also explain the change - the first involving a region containing both the ATP9 and SrRNA genes, and the second involving only the SrRNA gene. Our data demonstrate that large-scale rearrangements are rare events in Suillus mtDNA evolution. However, our approach is unlikely to detect small rearrangements, such as changes between probed regions and inversions of single unoriented genes.

\section{Discussion}

Insertions and deletions are the most striking feature of the intraspecific variation in $S$. viscidus and $S$. luteus. Size differences have been reported previously in different strains of Saccharomyces cerevisiae, Cochliobolus heterostrophus, Aspergillus nidulans, Neurospora crassa, Agaricus bitorquis, and Achyla spp. (Sanders et al. 1977; Earl et al. 1981; Collins and Lambowitz 1983; Garber and Yoder 1984; Hintz et al. 1985; Shumard et al. 1986; Taylor et al. 1986). In Saccharomyces cerevisiae, most of the interstrain size differences are attributable to changes in number of introns in COI, COB, and the LrRNA gene. Intergenic length mutations and mini-inserts in the Var1 and SrRNA genes account for an additional, but smaller, proportion of size differences (de Zamoraczy and Bernardi 1985). In Neurospora, a large proportion of the size variation may also result from optional introns. The regions containing $\mathrm{COB}$ and $\mathrm{COI}$ are highly variable in size, and in the case of the latter gene this variation has been shown to result from four optional introns (Collins and Lambowitz 1983). The NADH dehydrogenase subunit 1 gene (ND1) contains an intron in Neurospora crassa 740R (Burger and Werner 1985) that appears to correspond to a $1.2 \mathrm{~kb}$ optional insert described earlier (Mannella and Lambowitz 1979).

By analogy, one might expect much of the size variation within $S$. viscidus and $S$. luteus to be caused by optional introns. However, five of the size changes in $S$. viscidus (Fig. 2A: +0.7, $-0.6,+2,-3,-3.9$ ) and the largest size difference in S. luteus (Fig. 2B: -3.5 ) do not occur near any mapped genes known to contain introns in other fungi. Introns have also been found in genes for four of six NADH dehydrogenase subunits, ND1, ND3, ND4L, and ND5 (Burger and Werner 1985; Cummings et al. 1985; deVries et al. 1986; Nelson and Macino 1987), none of which we have mapped. If these genes are present in Suillus mitochondrial genomes and also contain optional introns, then some of these size differences might be explained.

A few of the size differences in Suillus could occur within genes that we did map. Size variation in the COI region provides the best examples. The likelihood of introns occurring within the Suillus gene seems high since introns have been found in COI in at least some strains of all fungi for which sequences or transcripts data exist (Bonitz et al. 1980; Clark-Walker and Sriprakash 1983; Collins and Lambowitz 1983; Lang 1984; Osiewacz and Esser 1984; Waring et al. 1984). The probe used to map the gene in Suillus is a 280 bp portion of the fifth exon from Saccharomyces cerevisiae (see Shumard et al. 1986). The entire coding sequence of the Saccharomyces gene is approximately $1,500 \mathrm{bp}$. Including introns, it can span $11,000 \mathrm{pb}$ (de Zamaroczy and Bernardi 1985). Thus, the Suillus COI gene could 
Table 1. Mitochondrial genome sizes of selected species of Suillus

\begin{tabular}{ll}
\hline Species & Genome size \\
\hline Suillus cavipes & 36 \\
S. ochraceoroseus & 41 \\
S. variegatus & 41 \\
S. tomentosus & 43 \\
S. spectabilis & 50 \\
S. sinuspaulianus & 50 \\
S. subalutaceus & 58 \\
S. placidus & 62 \\
S. americanus & 66 \\
S. brevipes & 68 \\
S. tridentinus & 68 \\
S. neoalbidipes & 84 \\
S. grevillei & 85 \\
S. spraguei & 104 \\
S. luteus & 104,106 \\
S. viscidus & 104,108 \\
S. grisellus & 121 \\
\hline
\end{tabular}

Genome sizes for the five species discussed in this paper were determined by the sum of site-to-site distances for the composite site maps shown in Figs. 2 and 4. All other sizes are averages of the sums of restriction fragments produced by HaeIII, Avall, and EcoRI digests (Bruns and Palmer, unpublished data). Sizes of two different strains of $S$. luteus and $S$. viscidus are given (Fig. 2)

easily overlap two large size differences in $S$. luteus and two small ones in $S$. viscidus (Fig. 2A, B). Two small size-variable regions of $S$. viscidus occur in the neighborhood of the ATP6 and the LrRNA genes. The former has an intron in Neurospora crassa, and the latter contains an intron in many fungi (Heckman and RajBhandary 1979; Lazarus et al. 1980; Jacquier and Dujon 1983; Wright and Cummings 1983).

We observed fewer size and restriction-site differences between the two $S$. luteus isolates than between the two $S$. viscidus strains. This finding may be simply an artifact of the small sample sizes and the higher density of mapped sites in the $S$. viscidus genomes. Nonetheless, it is curious, since the two isolates of $S$. luteus come from different continents, while those of $S$. visci$d u s$ are derived from adjacent counties in southeastern Michigan. S. luteus may be a European species that has only been introduced to North America in modern times along with European pines (O, K. Miller, personal communication). If this hypothesis is correct, then the low level of divergence found is not so surprising.

The level of mtDNA size variation $(36-121 \mathrm{~kb})$ found among the Suillus species studied is similar to that found within a group of interrelated yeast genera (28.5-101.1 kb, Hoeben and Clark-Walker 1986), and spans about half the range, $19-176 \mathrm{~kb}$, reported for all fungal mtDNAs (Clark-Walker 1985; Hintz et al. 1985). Additional species investigated within the genus Suillus fall in the range between 36 and $121 \mathrm{~kb}$ (Table 1) and exhibit a nearly continuous distribution of sizes. A comparison of the mtDNAs of $S$. cavipes and $S$. viscidus (Fig. 4) shows that not only is gene order identical, but the relative spacing between genes is similar; the smaller mitochondrial genome looks roughly like a uniformly shrunken version of the larger one. This pattern suggests that most regions of the molecule have been affected by length mutations and that the net direction of these changes has been the same throughout. These results, combined with the large amount of intraspecific variation observed, are consistent with the idea that the largest size differences observed among the distantly related taxa represent the gradual accretion of numerous small events. Large size differences between distantly related fungi, such as Aspergillus nidulans, Schizosaccharomyces pombe, and Saccharomyces cerevisiae, are primarily the result of differences in the amount of A-T rich intragenic DNA. Gene content, with the exception of NADH dehydrogenase and maturase genes, remains constant (Brown et al. 1985; Clark-Walker 1985).

Most prior studies have documented unique mitochondrial gene orders in every fungal species examined. It is not surprising, therefore, that both gene orders found in Suillus differ from previously reported ones. What is significant is that molecules that vary threefold in size share a common order and that the two different orders found are interconvertible by a single transposition. This conservation of gene order in these mitochondrial genomes demonstrates the rarity of rearrangements relative to insertions and deletions.

Calculation of nucleotide sequence divergence among the molecules is not possible from these data owing to the confounding effects of large-scale size-variation. Nevertheless, the number of restriction-site differences (10 out of 46 ) between $S$. viscidus and $S$. grisellus in regions without detectable size differences (Fig. 2), and the extremely limited restriction-site similarity between more distantly related species suggest that significant base substitution has also occurred in these mtDNA molecules.

Similarity in mitochondrial gene arrangements has been noted previously and interpreted as evidence for slow rates of gene-order change, but multiple rearrangements were always necessary to account for the different orders found (Macino et al. 1980; Grossman and Hudspeth 1985). A recent study of mtDNAs in Dekkera, Brettanomyces and Eeniella documented a mtDNA size range of $28.5-101.1 \mathrm{~kb}$. Identical gene arrangements were found in the smaller molecules, which ranged in size from $28-42 \mathrm{~kb}$ (Hoeben and Clark-Walker 1985). This was the first report of identical gene orders in mtDNAs with large size differences. Multiple rearrangements, however, were still necessary to explain the size differences between these small molecules and those 
of related taxa with sizes of 57 to $101 \mathrm{~kb}$ (Hoeben and Clark-Waiker 1986). The contrast between the extreme gene-order conservation found within Suillus and the high gene-order plasticity found previously may reflect a closer evolutionary relationship among the Suillus species studied relative to taxa compared in previous studies. These results reinforce the idea that mitochondrial gene order is a phylogenetically conservative character that varies slowly compared to size and primary sequence.

Acknowledgements. We thank R. D. Fogel, R. L. Shaffer, and W. M. Brown for critical reading of the manuscript, $\mathrm{H}$. Besl for European cultures of Suillus, and D. J. Bay for expert photography. Funding was provided by NIH grant GM-26546 to L. I. Grossman, NSF grant BSR-851665 to T. D. Bruns, J. D. Palmer, and R. L. Shaffer, NSF grant DCB-8451660 to J. D. Palmer, and a Horace H. Rackham fellowship to T. D. Bruns.

\section{References}

Bonitz SG, Coruzzi G, Thalenfeld BE, Tzagoloff A, Macino G (1980) J Biol Chem 255:11927-11941

Brown TA, Waring RB, Scazzocchio C, Davies RW (1985) Curr Genet 9:113-117

Burger G, Werner S (1985) J Mol Biol 186:231-242

Clark-Walker GD (1985) In: Cavalier-Smith T (ed) The evolution of genome size. Wiley, NY, pp 277-297

Clark-Walker GD, Sriprakash KS (1983) EMBO J 2:1465-1472

Collins RA, Lambowitz AM (1983) Plasmid 9:53-70

Coruzzi G, Tzagoloff A (1979) J Biol Chem 254:9324-9330

Cummings DJ, MacNeil IA, Domenico J, Matsuura ET (1985) J Mol Biol 185:659-680

DeVries H, Alzner-DeWeerd B, Breitenberger CA, Chang DD, de Jonge JC, RajBhandary UL (1986) EMBO J 5:779-786

De Zamaroczy M, Bernardi G (1985) Gene 37:1-17

Earl AJ, Turner G, Croff JH, Dales RBG, Lazarus CM, Lunsdorf H, Kuntzel H (1981) Curr Genet 3:221-228

Garber RC, Yoder OC (1984) Curr Genet 8:621-628

Grossman LI, Hudspeth MES (1985) In: Bennet JW, Linda L (eds) Gene manipulations in fungi. Academic Press, NY, pp 56-104

Heckman JE, RajBhandary UL (1979) Cell 17:583-595

Hintz WE, Mohan M, Anderson JB, Horgen P (1985) Curr Genet 9:127-132

Hoeben P, Clark-Walker GD (1986) Curr Genet 10:371-379

Hudspeth MES, Shumard DS, Tatti KM, Grossman LI (1980) Biochem Biophys Acta 610:221-228
Hudspeth MES, Shumard DS, Bradford CJR, Grossman LI (1983) Proc Natl Acad Sci USA 80:142-146

Jacquier A, Dujon B (1983) Mol Gen Genet 192:487-499

Lang BF (1984) EMBO J 3:2129-2136

Lang BF, Ahne F, Distler S, Trinkel H, Kaudewitz F, Wolf $\mathrm{K}$ (1983) In: Schweyen RJ, Wolf K, Kaudewitz F (eds) Mitochondria 1983: nucleo-mitochondrial interactions. de Gruyter, Berlin New York, pp 313-329

Lazarus CM, Lunsdorf H, Han U, Stepien PP, Kuntzel H (1980) Mol Gen Genet 177:389-397

Li M, Tzagoloff A, Underbrink-Lyon K, Martin N (1982) J Biol Chem 257:5921-5928

Macino G, Scazzocchio C, Waring RB, Berks MM, Davies RW (1980) Nature 288:404-406

McArthur CR, Clark-Walker GD (1983) Curr Genet 7:29-35

Maniatis T, Fritsch EF, Sambrook J (1982) Molecular cloning: a laboratory manual. Cold Spring Harbor Laboratory, Cold Spring Harbor, NY

Mannella CA, Lambowitz AM (1979) Genetics 93:645-654

Nelson MA, Macino G (1985) In: Quagilariello E, Slater EC, Palmier F, Saccone C, Kroon AM (eds) Achievements and perspectives in mitochondrial research, vol II. Biogenesis Elsevier Sci Publ, Amsterdam New York Oxford, pp 293-304

Nelson MA, Macino G (1987) Mol Gen Genet 206:318-325

Osiewacz HD, Esser K (1984) Curr Genet 8:299-305

Pegler DN, Young TWK (1981) Trans Br Mycol Soc 76:103-146

Pomerleau R, Smith AH (1962) Brittonia 14:156-172

Reed KC, Mann DA (1985) Nucleic Acids Res 13:7207-7221

Sanders JPM, Heyting C, Verbeet MP, Meijlink CPW, Borst P (1977) Mol Gen Genet 157:239-261

Shumard DS, Grossman LI, Hudspeth MES (1986) Mol Gen Genet 202:16-23

Singer R (1975) The agaricales in modern taxonomy. 3rd ed., Cramer, Vaduz

Singer R (1981) Persoonia 11:269-302

Smith AH, Thiers HD (1964) A contribution toward a monograph of the genus Suillus. Privately printed, Ann Arbor, MI

Smith AH, Thiers HD (1971) The boletaceae of Michigan. University of Michigan, Ann Arbor, MI

Sor F, Fukuhara H (1980) C R Acad Sci Paris 291:933-936

Southern EM (1975) J Mol Biol 98:503-517

Stevens RB (ed) (1984) Mycology guidebook. University of Washington, Seattle

Taylor JW, Smolich BD, May G (1986) Evolution 40:716-739

Tzagoloff A, Myer AM (1986) Annu Rev Biochem 55:249-285

Waring RB, Brown TA, Ray JA, Scazzocchio C, Davies RW (1984) EMBO J 3:2121-2128

Wright RM, Cummings DJ (1983) Curr Genet 7:151-157

Communicated by C. W. Birky Jr

Received September 11, 1987 / October 1, 1987 